\title{
A Century of International Affairs Think Tanks in Historical Perspective
}

For just over a century, think tanks have sought to play a role in the formulation and implementation of foreign policy. A recent study highlights how, in the past quarter century, the world's most successful and influential think tanks, while retaining a national base or headquarters, have sought to operate on a global scale, establishing branches beyond their home country or working with international networks of institutions or personnel. ${ }^{1}$ The first think tank to specialize in international affairs was the Royal United Services Institution (today the Royal United Services Institute for Defense and Security Studies), established in 1831 by the Duke of Wellington as an independent professional body to study military and strategic issues. ${ }^{2}$ The early twentieth century, however, was the most significant period in terms of the creation of several pioneering private organizations specializing in the study of contemporary international affairs. Institutions that originated then have often not only survived to the present, but are currently recognized as preeminent leaders among all think tanks, with Chatham House, the Carnegie Endowment for International Peace, and the Council on Foreign Relations all listed among the world's top ten think tanks overall. In 2014, twelve of the world's top twenty think tanks and approximately sixty of the top hundred specialized in foreign affairs, and for many if not most of the remainder international issues of some variety featured prominently on their agenda. ${ }^{3} \quad$ Political leaders now consider the presence in their states of credible and internationally respected think tanks that can contribute to framing the global intellectual agenda and provide concepts and ideas that become part of the currency of international discourse as a marker of a country's international standing, prestige, and soft power. Chinese President Xi Jinping has repeatedly proclaimed his intention of ensuring that China possesses such institutions, clearly regarding these as being among the necessary and desirable trappings and accessories of the international great power China aspires to be. Indeed, he views developing "a new type of think tank with Chinese characteristics" as essential to China's ability to compete with the United States. ${ }^{4}$ Since World War II, and even more in the decades from the 1980s onward, in every region of the world the number of think tanks has mushroomed dramatically, with 6,618 —a decline of 208 over the previous year-listed in the 2014 Go To Global Think Tank Index. ${ }^{5}$ One eminent Canadian expert on think tanks has gone so far as to enquire, "Do

1 James G. McGann with Richard Sabatini, Global Think Tanks: Policy Networks and Governance (New York: Routledge, 2011).

${ }^{2}$ Information taken from RUSI website, rusi.org.

${ }^{3}$ Data taken from the 2013 and 2014 Go To Global Think Tank Index of the Think Tanks and Civil Society Program of the University of Pennsylvania's Lauder Institute, published online at http://gotothinktank.com/.

4 See, for example, Cary Huang, “Think Tanks Face Hurdle in Answering Xi Jinping's Call," South China Morning Post, November 3, 2014.

${ }^{5}$ See also McGann with Sabatini, Global Think Tanks, 41-44; and the Think Tanks and Civil Societies Working Paper Series published by the Foreign Policy Research Institute of the University of Pennsylvania, Philadelphia. 
Think Tanks Matter?” Clearly, as his own work demonstrates, they do, perhaps never more so than today. ${ }^{6}$

Substantial literature exists on the broad subject of think tanks and their role in policymaking, particularly in relation to domestic affairs. Some works focus upon specific think tanks, while others consider at the phenomenon more generally. In addition to studies by McGann and Abelson, among the most stimulating general works are efforts by Diane Stone and others to define the differing national traditions of think tanks across Europe, North America, and parts of East and Southeast Asia. ${ }^{7}$ The subset of think tanks dealing specifically with international affairs has attracted far less scrutiny. McGann has highlighted how in recent years efforts and initiatives by globally active think tanks have helped to facilitate the introduction and implementation of market reform and democratization, effectively complementing, supplementing, and furthering policies favored by Western governments at the official level. ${ }^{8}$ Historical studies of think tanks specializing in international affairs have, however, been rather more limited. A significant number of works focus upon particular organizations, most notably the Round Table, the Council on Foreign Relations (CFR), the Institute of Pacific Relations (IPR), the Royal Institute of International Affairs (Chatham House or RIIA), the RAND Corporation, the Australian Institute of International Affairs (AIIA), the Canadian Institute of International Affairs (CIIA), and the Trilateral Commission (TC). ${ }^{9}$ Warren Kuehl has

${ }^{6}$ Abelson, Donald E. Abelson, Do Think Tanks Matter? Assessing the Impact of Public Policy Institutes, 2nd ed. (Montreal and Kingston, Canada: McGill-Queen’s University Press, 2009).

7 Diane Stone, Capturing the Political Imagination: Think Tanks and the Policy Process (London: Frank Cass, 1996); idem, Knowledge Actors and Transnational Governance: The Private-Public Policy Nexus in the Global Agora (Houndmills: Palgrave Macmillan, 2013); Diane Stone, Andrew Denham, and Mark Garnett, eds., Think Tanks Across Nations: A Comparative Approach (Manchester, UK: Manchester University Press, 1998); Diane Stone and Andrew Denham, eds. Think Tank Traditions: Policy Research and the Politics of Ideas (Manchester, UK: Manchester University Press, 2004). Other significant works by McGann include Competition for Dollars, Scholars and Influence in the Public Policy Research Industry (Lanham, MD: University Press of America, 1995); The International Survey of Think Tanks (Philadelphia: Foreign Policy Research Institute, 1999); Comparative Think Tanks, Politics and Public Policy (Northampton, MA: Edward Elgar, 2005); Think Tanks and Policy Advice in the U.S.: Academics, Advisors and Advocates (London, UK: Routledge, 2007); Democratization and Market Reform in Developing and Transitional Countries (London, UK: Routledge, 2010); and James McGann and Kent B. Weaver, eds., Think Tanks and Civil Societies: Catalyst for Ideas and Action (Piscataway, NJ: Transaction Publishers, 2000).

${ }^{8}$ McGann, Democratization and Market Reform in Developing and Transitional Countries.

9 Alex May, “The Round Table, 1910-66” (DPhil thesis, University of Oxford, 1995); Walter Nimocks, Milner's Young Men: The “Kindergarten” In Edwardian Imperial Affairs (Durham, NC: Duke University Press, 1968); John Kendle, The Round Table Movement and Imperial Union (Toronto, Canada: Toronto University Press, 1975); Andrea Bosco and Alex May, eds., The Round Table: The Empire/Commonwealth and British Foreign Policy (London, UK: Lothian Foundation Press, 1997); Laurence H. Shoup and William Minter, Imperial Brain Trust: The Council on Foreign Relations and United States Foreign Policy (New York: Monthly Review Press, 1977); Robert D. Schulzinger, The Wise Men of Foreign Affairs: The History of the Council on Foreign Relations (New York: Columbia University Press, 1984); Carlo Santoro, 
highlighted the interwar role of the US Foreign Policy Association. ${ }^{10}$ Studies by Christopher Thorne, Wm. Roger Louis, James Eayrs, and Priscilla Roberts have elucidated the contributions of Chatham House, the IPR, and the CIIA to Allied colonial policy during World War II. ${ }^{11}$ Biographical and autobiographical works focus upon some of the more prominent figures associated with these organizations. ${ }^{12}$ The major philanthropic organizations that have provided

Diffidence and Ambition: The Intellectual Sources of U.S. Foreign Policy (Boulder, CO: Westview, 1991); Michael Wala, Winning the Peace: The Council on Foreign Relations and American Foreign Policy in the Early Cold War (Providence, RI: Berghahn Books, 1994); Inderjeet Parmar, Think Tanks and Power in Foreign Policy (London: Palgrave Macmillan, 2004); Peter Grose, Continuing the Inquiry: The Council on Foreign Relations from 1921 to 1996 (New York: Council on Foreign Relations, 1996); Tomoko Akami, Internationalizing the Pacific: The United States, Japan and the Institute of Pacific Relations in War and Peace, 19191945 (New York: Routledge, 2002); Paul F. Hooper, Elusive Destiny: The Internationalist Movement in Modern Hawaii (Honolulu: University Press of Hawaii, 1980); Paul F. Hooper, ed., Rediscovering the IPR (Honolulu: University of Hawaii-Manoa, 1994); Hooper, ed., Remembering the Institute of Pacific Relations: The Memoirs of William L. Holland (Tokyo, Japan: Ryukei shosha, 1998); Study Group on the IPR, ed., The Institute of Pacific Relations: Pioneer International Non-Governmental Organization in the Asia-Pacific Region (Tokyo, Japan: Waseda University, 1999); John N. Thomas, The Institute of Pacific Relations: Asian Scholars and American Politics (Seattle: University of Washington Press, 1974); Andrea Bosco and Cornelia Navari, eds., Chatham House and British Foreign Policy 1919-1945 (London, UK: Lothian Foundation Press, 1994); John D. Legge, Australian Outlook: A History of the Australian Institute of International Affairs (Canberra: Australian National University and Allen and Unwin, 1999); Peter St. John, ed., From the Great War to the Global Village: A Window on the World (Winnipeg, Canada: Heartland Associates, 2005; Willis H. Ware, RAND and the Information Evolution: A History in Essays and Vignettes (Santa Monica, CA: Rand Corporation, 2008); Holly Sklar, ed., Trilateralism: The Trilateral Commission and Elite Planning for World Management (Boston, MA: South End Press, 1980).

${ }^{10}$ Warren F. Kuehl and Lynne K. Dunn, Keeping the Covenant: American Internationalists and the League of Nations, 1920-1939 (Kent, OH: Kent State University Press, 1997).

11 James W. Eayrs, In Defence of Canada: Peacemaking and Deterrence (Toronto, Canada: Toronto University Press, 1967), 209-216; Wm. Roger Louis, Imperialism at Bay 1941-1945: The United States and the Decolonization of the British Empire (Oxford, UK: Clarendon Press, 1977); Christopher Thorne, Allies of a Kind: The United States, Britain and the War Against Japan, 1941-1945 (New York: Oxford University Press, 1974); Christopher Thorne, "Chatham House, Whitehall, and Far Eastern Issues, 1941-1945," International Affairs 54:1 (January 1978), 1-29; Priscilla Roberts, “Tweaking the Lion’s Tail: Edgar J. Tarr, the Canadian Institute of International Affairs, and the British Empire, 1931-1950," Diplomacy and Statecraft 23:4 (December 2012): 636-659.

12 See, for example, Hamilton Fish Armstrong, Peace and Counterpeace from Wilson to Hitler: Memoirs of Hamilton Fish Armstrong (New York: Harper and Row, 1971); Adam Chapnick, Canada's Voice: The Public Life of John W. Holmes (Vancouver, Canada: University of British Columbia Press, 2009); John Merle Davis, John Merle Davis: An Autobiography (Tokyo, Japan: Kyo Bun Kwan, 1959); Deborah Lavin, From Empire to Imperial Commonwealth: A Biography of Lionel Curtis (Oxford, UK: Clarendon Press, 1995); James T. Shotwell, The Autobiography of 
much of the financial backing for foreign policy think tanks around the world have also been the subject of several insightful studies. ${ }^{13}$ As yet, however, there has been no serious effort to consider, assess, and understand from a broad perspective, rather than in terms of individual empirical studies and institutional histories, the phenomenon of foreign policy think tanks and the intellectual networks and knowledge regimes that they created and constituted. With the centenaries of several leading foreign policy think tanks already past or approaching in the next few years, the time seems ripe for efforts to provide a nuanced assessment and overview of their significance in the making of twentieth and early twenty-first century foreign policy and suggest what their potential future may be.

It may be anachronistic even to use the label "think tank," a coinage of the 1960s, in connection with early institutions now categorized as such. Noting that each of the American organizations concerned generally regarded itself as sui generis in nature and function, Thomas Medvetz prefers to term these "proto-think tanks." 14 Institutes of international affairs, institutions where academic experts, official and non-official practitioners, and others with an interest in foreign policy could come together, focus upon immediate and long-term international issues, suggest potential ways of handling these, and attempt to steer governmental policies and influence public opinion, were initially a creation of the early twentieth century. Several impulses contributed to their emergence. One was the progressive and liberal faith of the late nineteenth and early twentieth centuries, that by deploying enlightened expertise and scientific knowledge, men and women of goodwill could come up with solutions to all existing problems, an outlook that led to the emergence of such reformist organizations as the Fabian Society in Britain and the National Civic Federation in the United States. ${ }^{15}$ A second was the influential international arbitration and peace movement of the period, which prompted the establishment in 1910 of both the Bostonbased World Peace Foundation (originally the International School of Peace) and the Carnegie Endowment for International Peace, each funded by a wealthy American businessman and

James T. Shotwell (New York: Bobbs-Merrill, 1961); Ray Lyman Wilbur, The Memoirs of Ray Lyman Wilbur (Stanford: Stanford University Press, 1960); Priscilla Roberts, “"The Council Has Been Your Creation': Hamilton Fish Armstrong, Paradigm of the American Foreign Policy Establishment?,” Journal of American Studies 35:1 (April 2001), 65-94; Priscilla Roberts, "Frank Altschul, Lazard Frères, and the Council on Foreign Relations: The Evolution of a Transatlantic Thinker,” Journal of Transatlantic Studies, 1:2 (Autumn 2003), 175-213.

13 Edward H Berman, The Influence of the Carnegie, Ford and Rockefeller Foundations on American Foreign Policy: The Ideology of Philanthropy (Albany: State University of New York Press, 1984); Mary Brown Bullock, The Oil Prince's Legacy: Rockefeller Philanthropy in China (Stanford: Stanford University Press, 2011); Ellen Condliffe Lagemann, The Politics of Knowledge: The Carnegie Corporation, Philanthropy, and Public Policy (Middletown, CT: Wesleyan University Press, 1989); Inderjeet Parmar, Foundations of the American Century (NY: Columbia University Press, 2012); Olivier Zunz, Philanthropy in America: A History (Princeton: Princeton University Press, 2011).

14 Thomas Medvetz, Think Tanks in America (Chicago: University of Chicago Press, 2012), 4783.

${ }^{15}$ Christophe J. Cyphers, The National Civic Federation and the Making of a New Liberalism, 1900-1915 (Westport, CT: Praeger, 2002). 
intended to promote international peace and understanding. ${ }^{16}$ A third was the concern of influential and well-placed elite individuals and groups within the British Empire to strengthen the ties among its constituent parts by encouraging greater unity and coordination of policy, especially in the fields of defense and strategic thinking, a movement that led first to the foundation of the Rhodes Trust and then, in 1910, to the formation of the trans-dominion Round Table groups and the journal to which members from around the empire contributed.

A fourth, catalytic impulse was the multifaceted experience of World War I itself. In the United States, during the years of neutrality, the Navy League, the Military Training Camps Association (Plattsburg movement), and the National Security League all lobbied for major increases in American defense budgets and military ‘preparedness,' efforts that normally had a strongly prointerventionist flavor. ${ }^{17}$ The Council on Foreign Relations, a group of businessmen, lawyers, and others with an interest in international affairs, came into existence after US intervention as an organization that held regular meetings focusing on foreign issues. British wartime organizations lobbying for the establishment of a postwar international organization to prevent future wars included the League of Nations Society and the League of Free Nations Association. In the United States, the League to Enforce Peace (founded 1915) and the more overtly Wilsonian League of Free Nations Association (founded 1918, reincarnated in 1923 as the Foreign Policy Association) took up the same cause. These impulses all came together at the 1919 Paris Peace Conference. The US and British delegations, in particular, each included not just diplomats, but substantial cohorts of experts drawn from business, academe, and the media, and seconded into military or other government posts service thanks to wartime demands. In the United States, President Woodrow Wilson's close adviser Colonel Edward M. House had assembled a substantial group of specialists in the body known as "The Inquiry," formed to devise a detailed blueprint for the coming peace settlement. The wartime British Foreign Office enlisted a number of outside academic experts, including Lewis Namier, Arnold Toynbee, and Alfred Zimmern, in the Political Intelligence Department. ${ }^{18}$ In May 1919, with the end of the peace conference anticipated before long, the British and American experts held a meeting at which each side

16 C. Roland Marchand, The American Peace Movement and Social Reform, 1898-1918 (Princeton: Princeton University Press, 1973); David S. Patterson, Toward a Warless World: The Travail of the American Peace Movement, 1887-1914 (Bloomington: Indiana University Press, 1977).

17 John Carver Edwards, Patriots in Pinstripe: Men of the National Security League (Lanham, MD: University Press of America, 1982); Armin Rappaport, The Navy League of the United States (Detroit, MI: Wayne State University Press, 1962); John Garry Clifford, The Citizen Soldiers: The Plattsburg Training Camp Movement, 1913-1920 (Lexington: University Press of Kentucky, 1982); Michael D. Pearlman, To Make Democracy Safe for America: Patricians and Preparedness in the Progressive Era (Urbana: University of Illinois Press, 1984).

18 On the Paris Peace Conference, see Margaret MacMillan, Paris 1919: Six Months That Changed the World (New York: Random House, 2002); on the "Inquiry," see Lawrence E. Gelfand, The Inquiry: American Preparations for Peace, 1917-1919 (New Haven, CT: Yale University Press, 1962); on Colonel House, see Charles E. Neu, Colonel House: A Biography of Woodrow Wilson's Silent Partner (New York: Oxford University Press, 2014); and Godfrey Hodgson, Woodrow Wilson's Right Hand: The Life of Colonel Edward M. House (New Haven, CT: Yale University Press, 2006). 
decided to establish a permanent organization that would focus upon conducting research and providing top-level information on international affairs.

The British Institute of International Affairs, blessed with influential patrons within and outside government, was established rather quickly. One year later the organization held its inaugural meeting, and in 1922 the BIIA (soon to become the Royal Institute of International Affairs (RIIA), when it was given a royal charter) acquired a mansion in St. James's Square, the former home of British Prime Minister William Pitt, the Earl of Chatham, a key figure in British imperial history. Over the next decade key figures in Chatham House, as the RIIA was often known, encouraged the establishment of affiliated Institutes of International Affairs in the British dominions, Canada, New Zealand, Australia, and South Africa. The American Institute of International Affairs had a more troubled early history, almost foundering in its first two years, before merging in 1921 with the existing New York-based and more business-oriented Council on Foreign Relations (CFR). At least initially, some of the original AIIA members were somewhat uncomfortable with this alliance, fearing that it would compromise the intellectual integrity of the new Council. In practice, the body's wealthy membership and geographical proximity to the New York-based philanthropic foundations that were becoming ever more significant sources of funding for internationalist ventures of every kind helped to ensure not just its survival but also its standing as an increasingly prestigious and respected voice on international policy. ${ }^{19}$

A generous founding patron could indeed make all the difference. In 1919 the wealthy businessman and engineer Herbert Hoover, a millionaire who had made a fortune in international ventures in China and elsewhere, before heading up first Belgian wartime relief and then broader American relief efforts in Europe and Russia that would extend well into the 1920s, founded the Hoover Institution on War, Revolution, and Peace at Stanford University, his alma mater. In subsequent years, this research institute would not only amass stunning documentary collections on China and Russia, together with major archival holdings of US political personalities and organizations, but provide moderately conservative scholars and intellectuals with a useful base. At this time, though, Hoover regarded himself as a liberal progressive, not the diehard conservative of subsequent legend. $^{20}$ In 1919 Edward Filene, another liberal American businessman, established the Twentieth Century Fund (now the Century Foundation) to promote progressive causes at home and abroad, including how best to ensure international peace. ${ }^{21}$

The experience of Versailles and probably the Anglo-American example impelled other European nations - some of which had indeed only recently come into existence - to follow suit and establish their own international affairs institutes. The German delegation established the

\footnotetext{
${ }^{19}$ Much of the information on specific foreign policy think tanks in this article is drawn from my own research in the archives of these organizations. On the early history of the Council on Foreign Relations, see also the works cited earlier, and Whitney H. Shepardson, Early History of the Council on Foreign Relations (Stamford, CT: Overbrook Press, 1960). The annual reports of the various organizations are also valuable sources on their activities and membership.

${ }^{20}$ Stone, Capturing the Political Imagination, 191.

${ }^{21}$ A. A. Berle, Leaning Against the Dawn: An Appreciation of the Twentieth Century Fund and Its Fifty Years of Adventure in Seeking to Influence American Development Toward a More Effectively Just Civilization, 1919-1969 (New York: Twentieth Century Fund, 1969); on Filene, see Gerald W. Johnson, Liberal’s Progress (New York: Coward-McCann, 1948).
} 
Hamburg-based Institut für Auswärtige Politik, eventually disbanded by the Nazi government during the 1930s. ${ }^{22}$ A comparable Italian institute suffered a similar fate at Fascist hands. But others survived, at least temporarily. By the mid-1930s, Austria, Belgium, Denmark, France, Hungary, the Netherlands, Norway, Poland, Rumania, Spain, Sweden, Switzerland, and Yugoslavia, plus Brazil and Mexico, all possessed foreign affairs institutes, often openly modelled upon Chatham House. Frequently quite small, they helped to build national communities of elites interested in international affairs. In many cases, they were largely government-funded, though between the wars the Carnegie Corporation and Rockefeller Foundation also provided significant financial support to most such organizations, including the Chatham House-British Empire affiliates. ${ }^{23}$

Substantial US foundation funding was likewise undoubtedly a major factor in the establishment in 1925 and extensive activities over the next quarter-century of the Institute of Pacific Relations (IPR), the most ambitious effort to create not simply one national foreign policy think tank, but a transnational network of (usually) national organizations from more than a dozen states either located around the Pacific rim or with colonial interests in the area. This too was a response to Wilsonian efforts to devise a new, more just, and more peaceable international system. Established by Americans with close ties with the Young Men's Christian Association and associated missionary undertakings, its major activities included fortnight-long international conferences, held every two to three years, and a massive publications programme. John King Fairbank rightly recalled that before World War II, the IPR was one of the most impressive and even glamorous intellectual undertakings of its time. Chatham House and the Australian, Canadian, and New Zealand Institutes of International Affairs all belonged to the IPR network. Until World War II the IPR sought to discourage participation in its conferences by current (though not past) government officials. The IPR nonetheless sought to play a role in international diplomacy, in particular through efforts in the 1930s to mediate escalating conflicts between China and Japan, ventures that met little if any success. Ultimately, the IPR fell victim to increasingly forceful though largely ill-founded accusations levelled against it from the mid1940s onwards in the United States, that it had become a tool of Communist Chinese forces, whose political ends it sought to serve. ${ }^{24}$ To many executives of US foreign policy think tanks and the American philanthropic foundations and major donors that funded them, this experience became a cautionary tale of the need to observe discretion when dealing with politically sensitive questions, particularly anything China-related.

Between the world wars, foreign policy think tanks were involved in multiple ambitious and overlapping efforts to establish transnational networks of knowledge institutions that sought to underpin attempts to encourage international cooperation and understanding. One of these was

22 Stone, Capturing the Political Imagination, 191.

${ }^{23}$ Chadwick F. Alger, “Introduction” to Étienne Dennery, Le Problème des Matières Premières (New York: Garland, 1972), 10-11.

24 Akami, Internationalizing the Pacific; Hooper, Elusive Destiny; Hooper, ed., Rediscovering the IPR; Hooper, ed., Remembering the Institute of Pacific Relations; Thomas, The Institute of Pacific Relations; John King Fairbank, "William L. Holland and the IPR in Historical Perspective," Pacific Affairs 52:4 (Winter 1979-1980), 587-590; James Cotton, Asian Frontier Nationalism: Owen Lattimore and the American Policy Debate (Atlantic Highlands, NJ: Humanities Press, 1989); Robert P. Newman, Owen Lattimore and the "Loss" of China (Berkeley: University of California Press, 1992). 
the sprawling IPR network, which included not just much of Asia, Australasia, and North America, bur also Britain, France, and the Netherlands. A second, established in part by Chatham House as a means of keeping the British dominions institutes oriented towards the British Empire or Commonwealth as opposed to the US-dominated and somewhat anticolonial IPR, was the organization of the informal British Commonwealth Conferences, gatherings of the British empire institutes that took place at irregular intervals every few years, meetings held in Canada in 1933, Australia in 1938, London in 1944, and Canada in 1949. A third, closely associated with the League of Nations and largely organized by the Carnegie Endowment of International Peace, which maintained offices in Europe, was the Institute of Intellectual Cooperation network, which from the mid-1920s until 1939 held annual meetings of organizations involved in the study of international affairs, that brought together personnel from the various think tanks with those working in academic institutions with programmes in international relations or international affairs. Their yearly conferences, which sought to focus on controversial and topical international issues, devoted much attention in the 1930s to the subjects of collective security and peaceful-as opposed to violent forcible-change in international affairs. $^{25}$

The impact of the sometimes competing IPR and British Commonwealth networks of think tanks upon the British Empire was far from straightforward, especially in terms of whether these institutions and links helped to hold the British Empire together or, conversely, had a fissiparous effect, dissolving the ties with the metropole. On the whole, the answer seems to be that, though internal splits existed within its membership, the Canadian Institute of International Affairs increasingly became an organization whose influence tended to weaken imperial ties. In Australia and New Zealand this was far less the case, but those countries' Institutes nonetheless played a key role in encouraging the development of foreign policies that were oriented towards their specific needs and their geographical situation adjoining Asia. ${ }^{26}$ More broadly, the IPR challenged underlying colonial assumptions. From its inception, at least some IPR founders hoped to include Soviet representation, an objective that was fulfilled for some years in the mid1930s, when Soviet scholars from a Moscow-based Pacific Institute joined the organization and attended at least one conference. While their Asian colonies brought the inclusion of Dutch, French, and British member organizations, Chinese and Japanese Institutes were founding members of the IPR federation, a rare interwar instance of Asians and Westerners meeting on equal terms. Within a few years, a Philippine IPR also existed, a vector for nationalist sentiment. Both China and Japan sought to use the IPR framework to promote their own national interests, often criticizing each other's policies in Manchuria, but also protesting fiercely against Western colonial policies across Asia, special concessions in China, and racist attitudes. These activities won the Chinese IPR official financial support; after the 1933 IPR conference in Banff, Canada, for example, Chiang Kai-shek contributed \$50,000. In the 1930s and early 1940s, sympathetic American and Canadian IPR leaders encouraged Asian criticisms of European imperialism, and

${ }^{25}$ Kuehl and Dunn, Keeping the Covenant; Katharina Rietzler, "Experts for Peace: Structures and Motivations of Philanthropic Internationalism in the Interwar Years," esp. 51-58, in Internationalism Reconfigured: Transnational Ideas and Movements Between the Wars, ed. Daniel Laqua (London, UK: I. B. Tauris, 2011); Alger, “Introduction,” 5-18.

${ }^{26}$ See esp. Roberts, "Tweaking the Lion's Tail”; also Legge, Australian Outlook; James Cotton, The Australian School of International Relations (New York: Palgrave Macmillan, 2013). 
actively sought to make IPR conferences forums where Indian representatives could attack British policies and demand full independence. ${ }^{27}$

In the Anglo-American sphere, World War II impelled think tanks and their personnel into the centre of policy formulation, with think tank staffers and members providing an essential reservoir of expertise for policy analysis and long-term planning. In the immediate aftermath of World War II, this remained the case. The CFR was particularly significant in terms of serving as a forum where officials and other elites could debate and formulate developing US Cold War policies in private, before selling them to Congress and the public. ${ }^{28}$ Chatham House, the AIIA, and the CIIA also remained important in terms of helping to formulate and develop those countries' international policies. AIIA and CIIA efforts, in conjunction with the official Australian and Canadian foreign affairs bureaucracies, to publicize and mobilize popular support for their nations' international policies were another major element in their postwar activities. ${ }^{29}$

In the postwar world, however, international affairs institutes apparently soon came to function somewhat differently than between the wars. The far-flung networks of the interwar period shrank dramatically. The International Studies Conferences run by the Committee on Intellectual Cooperation never properly revived after 1945, though what remained of their assets and personnel were subsumed under the new UNESCO umbrella. In 1972, the author of the Introduction to a reprint edition of some of its conference volumes even lamented the absence at that time of any comparable effort "to assemble the most competent scholars in all countries for a collaborative assault on significant international problems," suggesting that, despite the existence of "a considerable amount of scholarly collaboration across national boundaries," future "historians . . . will wonder why scholars of the 1970s were not as energetic and creative in developing truly international institutions for inquiry." 30 With China lobby influence and McCarthyist anti-communism increasingly strong influences in the United States of the 1940s and early 1950s, the IPR's alleged penetration by Chinese and Soviet Communists attracted ferocious and incessant criticism, that ultimately caused the collapse of the American IPR and the overarching Pacific Council that had managed the international IPR organization. Except for the China Council, which withdrew in 1949, most of the IPR's other constituent national organizations remained in existence. The revived Japanese Council proved to be one channel for encouraging Japan's Cold War reintegration into the non-Communist international structure, while the Indian, Pakistani, Indonesian, and Philippine organizations were in each case associated with and markers of those nations' nationalist and independence movements. As Michael Anderson has pointed out, throughout the 1950s IPR international conferences continued, shifting venues around Asia and attended by substantial cohorts of Westernincluding US - and Asian scholars. ${ }^{31}$ After the late 1950s, however, these meetings fizzled out and so, slightly later, did the British Commonwealth Conferences, a victim of Chatham House's—and Britain's_-growing preoccupation with Europe and the Common Market.

${ }^{27}$ Akami, Internationalizing the Pacific; Roberts, “Tweaking the Lion’s Tail,” 636-659.

28 Akami, Internationalizing the Pacific; Parmar, Think Tanks and Power; Wala, Winning the Peace; Santoro, Diffidence and Ambition.

${ }^{29}$ Legge, Australian Outlook; St. John, ed., From the Great War.

${ }^{30}$ Alger, "Introduction," 16-17.

${ }^{31}$ Michael Anderson, "Pacific Dreams: The Institute of Pacific Relations and the Struggle for the Mind of Asia” (PhD. thesis, University of Texas, 2009). 
While political reasons may have accounted for the decline and ultimate disappearance of the marathon inter-war conferences, lasting a fortnight and demanding substantial investment in travel time and funds, logistics may also have played a part. Paradoxically, the emergence of relatively rapid air travel, facilitating personal contacts of every kind, may have made such gatherings and the sprawling networks they represented less salient to the academic policy world. So too, it seems, did the emergence of other centres for the study of international affairs and associated disciplines such as developmental economics, many based in top academic institutions. The Yale Institute of International Studies, established in the mid-1930s and funded by Carnegie and Rockefeller donations as well as private contributions, an early centre for the dissemination of what would soon become known as the Realist tradition of international relations, was probably the pioneer of such bodies. ${ }^{32}$ Other prominent American universities, especially the Ivy League, MIT, Michigan, Chicago, Stanford, and UC-Berkeley, soon proved hospitable to similar enterprises, especially when their study and research programmes succeeded in attracting substantial government and private funding. Within London University, the London School of Economics, the School of Oriental and African Studies, and King's College were more amenable than venerable but structurally rigid Oxford and Cambridge to housing innovative new programmes and centres. In Australia, the newly established Australian National University, based in Canberra, the capital, was intended to boost the study of Asia, the region to which, as Australians had by 1945 become extremely conscious, their country was geographically if not culturally closest, a factor that could not be ignored.

Links between the official policy world and civilian expertise proliferated at various levels. By the Second World War's end, for example, the British Foreign Office had taken over what had initially been a wartime research unit staffed by Chatham House personnel, now re-named the Foreign Office Research Department. In 1946 the US State Department established its own inhouse think tank, the Policy Planning Staff. The Defense Department's efforts to set up a comparable organization eventually led to the creation in 1956 of the Institute of Defense Analyses. The more technologically oriented RAND Corporation, an outgrowth of the US Air Force's wartime needs, came into being earlier, in the late 1940s. The Washington-based Brookings Institution did not concentrate exclusively on foreign affairs, but one substantial division focused on studies of international issues. With arms control and strategic and security issues pressing Anglo-American Cold War preoccupations, two major private research centres were founded in London and Washington. In 1958 the British military historian Sir Michael Howard, working with Labour politician Denis Healey and journalist Alistair Buchan, set up the International Institute for Strategic Studies. Its Washington counterpart was the Center for Strategic and International Studies, founded in 1962 by former Chief of Naval Operations Arleigh Burke and initially based at Georgetown University. Particularly in the post-1945 United States, but also elsewhere, independent foreign policy think tanks were only part of a broader complex of research organizations. ${ }^{33}$

This did not, however, mean that international affairs institutes had become irrelevant, nor that transnational interactions among them ceased. Rather, their modus operandi and cooperative arrangements adapted to changing national and global conditions. In Germany, Italy, and

32 Paulo J. B. Ramos, "The Role of the Yale Institute of International Studies in the Construction of United States National Security Ideology, 1935-1951” (PhD thesis, Manchester University, 2003).

${ }^{33}$ On post-1945 think tank proliferation, see McGann, Global Think Tanks, 40-43. 
occupied Europe, most such institutions had ceased operations during the 1930s or the early 1940s. After 1945, however, these organizations were either revived or replaced by new centres of some kind. The privately funded DGAP (German Council on Foreign Relations), founded in 1955, consciously modeled itself on its New York namesake. Other significant German foreign policy institutes, notably the SWP (German Institute for International and Security Affairs), were largely government-funded. So, too, was the Institut Français de Relations Internationales (IFRI), created in 1979 on the foundation of the Centre d'études de politique étrangère, the French version of Chatham House established in 1935. Virtually every West European country_-Italy, the Netherlands, Belgium, Denmark, Sweden, Norway, and Finland_-had at least one international affairs institute, often heavily reliant upon public funding if not part of the governmental apparatus. Norway also housed the independent Peace Research Institute Oslo (PRIO), founded in 1959, and Sweden the government-backed Stockholm International Peace Research Institute, established in 1964.

Think tanks specializing in international affairs were generally considered national assets, useful supplements to the bureaucracy charged with the day-to-day administration of foreign policy. They also provided convenient interfaces where politicians and bureaucrats could encounter not just ideas, but also individuals from the academic, media, and business worlds, potential supporters or even recruits for government operations. As Marshall Plan policies envisaging West Germany's economic recovery and political, economic, and military reintegration into Europe developed in the late 1940s and early 1950s, North American and West European international affairs think tanks organized assorted joint conferences in Europe focusing on these issues, where informed elites from countries promoting and those which would be affected by these new initiatives came together to discuss their implications for non-communist Europe.

For three decades after 1945, bilateral and occasionally trilateral initiatives and ad hoc meetings became the preferred international operating mode for the international affairs institutes. These often built on earlier relationships. The CFR and RIIA, originally envisaged in 1919 as Siamese twins, had a close relationship thereafter. In the 1920s and mid-1930s, and again in the early 1950s, they undertook joint studies intended to explore and resolve major tensions in AngloAmerican relations. In the 1960s and beyond, one key CFR figure, Miriam Camps, an American woman living in Britain and married to the master of Pembroke College, Cambridge, held joint appointments with both Chatham House and the Council, working on a wide-ranging series of studies that often involved personnel from both organizations, plus a cast of British and European contributors. In 1968, Chatham House and the Institute of Defense Analyses also cosponsored a conference on the future of Anglo-American relations. From the 1930s onward, the CFR and the Canadian Institute of International Affairs likewise had close ties. From the interwar period well into the 1980s, the two organizations held repeated joint conferences, usually resulting in co-publications, meetings where the participants hoped to illuminate, discuss, and defuse difficulties in their two countries' bilateral relationship. In the mid-1950s, one such meeting brought together the RIIA, CIIA, and CFR. In the mid-1950s, the CFR also mounted a joint project with the Indian Council of World Affairs, to explore contentious issues in USIndian relations. From the 1950s through the 1980s Chatham House, as British eyes turned increasingly towards Europe, mounted many successive conferences on intra-European relations, some of them trilateral, involving both French and German partner institutes, and some bilateral, with partners including France, Germany, Italy, and Norway. 
Supplementing these were a long series of meetings, from the 1960s to the 1980s, among directors of the European Institutes of International Affairs, meetings that transcended the Iron Curtain, bringing together institutes from both Eastern and Western Europe. All Eastern Europe's Soviet-bloc nations possessed one or more government-funded institutes or centres focusing upon international affairs, that maintained some contacts with Western counterparts. So too did the Soviet Union, with the Russian Institute for the USA and Canada and the Institute of World Economy and International Relations (IMEMO) the major contact points. Soviet-bloc scholars were often constrained in what they could write or publicly advocate, but these exchanges helped maintain communications at a semi-official level. One highly intriguing aspect of the Cold War period is how, from the 1960s to the 1980s, three leading AngloAmerican private institutes, the CFR, Chatham House, and the CIIA, each independently mounted a series of joint conferences, meetings and other contacts with comparable organizations in Hungary, Romania, Yugoslavia, Poland, and the Soviet Union, each involving a series of separate bilateral meetings. ${ }^{34}$ How far such initiatives and contacts facilitated and contributed to détente, the Helsinki process, and the relaxation of Soviet policies that eventually brought the ending of the Cold War is less than clear, and deserves further investigation. Undoubtedly, however, US, British, and Canadian diplomats in the countries involved and in Washington, London, and Ottawa were well aware of such contacts and often received reports on them. (Although the CFR prided itself on not accepting government funding, in these years both Chatham House and the CIIA sought and received substantial subsidies from their national foreign offices.)

The role of foreign policy think tanks in US relations with China, for two decades a missing quantity in the international equation, was equally significant. With the American IPR crippled by McCarthyite attacks, by the early 1950s China had become a radioactive topic in terms of public debate. The Asia Society, founded in the late 1950s by John D. Rockefeller III in an effort to fill the gap left by the near-defunct IPR, flatly refused even to consider taking any role on the IPR's Pacific Council, and initially excluded China from its areas of interest. Pressed by IPR representatives, Rockefeller "emphatically stated that the Society would not undertake research or publication of a journal, that it did not intend to operate outside the United States and that it proposed to concentrate its efforts for the present on social activities (dinner, receptions) and cultural projects (such as art exhibits). He also made it very clear that under no circumstances would the Society be willing to become the successor to the American IPR or to take over its functions in the international IPR at present or in the foreseeable future, and that this would still hold even if the international IPR should later change its name." 35 Under these

34 Strobe Talbott's introduction to the memoir of Georgi Arbatov, director of the Russian Institute for the USA and Canada and a leading interlocutor in these exchanges, quite vividly depicts some of the exchange relationships involved. Georgi Arbatov, The System: An Insider's Life in Soviet Politics (New York: Times Books, 1992). See also Stone, Denham, and Garnett, eds., Think Tanks Across Nations, 202-222; Stone and Denham, eds., Think Tank Traditions, 121-137; Metta Spencer, The Russian Quest for Peace and Democracy (Lexington: Rowman and Littlefield, 2010); and James Voorhees, Dialogue Sustained: The Multilevel Peace Process and the Dartmouth Conference (Washington, DC: United States Institute of Peace Press, 2002).

${ }^{35}$ J. Morden Murphy, To Trustees of the American IPR., January 21, 1957, Folder 25 Institute of Pacific Relations, Correspondence M 1945-1957, Box 1, William W. Lockwood Papers, Mudd Manuscripts Library, Princeton University. 
hostile conditions, in the 1950s and 1960s the once Eurocentric CFR became particularly significant in facilitating the continuation of informed debate on the highly controversial subject of China, providing a forum where elite policymakers, official and unofficial, could exchange views privately in strict confidentiality, and a new generation of experts on China and Asia were nurtured. Visiting foreign speakers, top government officials and private individuals alike, could explain and defend their own and their governments' stances on China, without risking public controversy. The publication of CFR studies on China helped to change the climate of public opinion and prepare the ground for recognition, as did the work of the National Committee on US-China Relations, established by leading US China experts in the mid-1960s and funded primarily by John D. Rockefeller III. Eventually the Asia Society likewise played a significant role. Although that body initially quite deliberately refrained from betraying any interest in China, this position changed from the mid-1960s, as the Asia Society organized its own China Council and began to host events featuring serious discussion of China policy. During the 1970s these interlinked institutions played significant parts in making contacts with Chinese elites of various kinds and smoothing the path towards full US diplomatic recognition of China. Subsequently, they effectively worked together to steer Sino-American relations through what were often troubled waters. ${ }^{36}$

If relations with China were uniquely contentious in the United States, in other countries China policy was nonetheless both disputed and intriguing. Britain recognized the new People's Republic of China within weeks of its proclamation. In the early 1950s, Chatham House and CFR representatives came together to explain their respective countries' differing policies on China nad other issues to each other, a project that resulted in a joint book publication. ${ }^{37}$ After Britain and China upgraded their diplomatic representation in the early 1970s, the RIIA made overtures to Chinese diplomats in London, and sought to develop relations with counterparts in China. $^{38}$ In Australia, New Zealand, and Canada, US pressure ensured that the decision to recognize China officially was deferred until the early 1970s, and during two decades of nonrecognition officials and the public alike split over this policy's merits. It appears probable that the international affairs institutes provided forums where dissenting views on China policy could be heard and discussed. Once relations were re-established, the institutes organized trips to

\footnotetext{
${ }^{36}$ On Rockefeller's support for these organizations, see Bullock, The Oil Prince's Legacy; John Ensor Harr, and Peter Dobkin Hall, The Rockefeller Century (New York: Scribner's, 1988) and The Rockefeller Conscience (New York: Scribner’s, 1991). On the Asia Society's operations, see Adriana Proser, ed., A Passion for Asia: The Rockefeller Legacy (New York: Asia Society, 2009); and Nicholas Platt, China Boys: How U.S. Relations with the PRC Began and Grew: A Personal Memoir (Washington, DC: New Academia Publishing, 2010). On National Council on US-China Relations operations, see its newsletters; also Norton Wheeler, The Role of American NGOs in China's Modernization: Invited Influence (New York: Routledge, 2012).

37 Henry L. Roberts and Paul A. Wilson, Britain and the United States: Problems in Cooperation: A Joint Report (New York: Harper, 1953).

38 On British policies, see Priscilla Roberts, "Rebuilding a Relationship: British Cultural Diplomacy Towards China, 1967-80,” in British Propaganda and Wars of Empire: Influencing Friend and Foe 1900-2010, eds. Greg Kennedy and Christopher Tuck (Farnham, UK: Ashgate, 2014), 191-218.
} 
China, hosted Chinese visitors and speakers and, increasingly, took part in joint events with Chinese counterpart bodies. ${ }^{39}$

From the 1970s, foreign policy think tank operating modes, especially in terms of transnational interchanges, seem once more to have evolved, adapting to altered conditions. There was a steady return to global rather than national emphasis, and a new readiness to contemplate ambitious international linkages. Responding to the pervasive sense of American decline (and its own perceived irrelevance and failures), with Ford and Rockefeller funding the CFR mounted a massive Project for the 1980s, intended to reshape US policy in an increasingly interdependent and globalized world. ${ }^{40}$ New emphasis on international interdependence and multilateralism brought an intensification of bilateral and trilateral joint ventures, with project teams now including well-qualified participants who were not necessarily nationals of the organizing country. Broadly speaking, from the mid-1970s onward foreign policy think tanks began to reinvent themselves. One reason was probably an increasing awareness that they must change or die. The small, clublike institutions of earlier decades, effectively run by a few energetic, sometimes charismatic enthusiasts, lacked the critical mass of personnel and organizational and technical skills needed to compete and make an impact on the national and increasingly the global stage. New institutional rivals for influence included highly politicized advocacy think tanks, committed to strongly ideological and usually conservative perspectives, with the American Enterprise Institute and the Heritage Foundation to the fore. A plethora of new singleissue non-governmental organizations, such as Amnesty International, Human Rights Watch, World Watch, and the International Crisis Group, focused upon particular international causes, such as the environment, human rights, or women's issues. And think tanks linked to the fortunes of specific political parties or groups, or designed to promote the interests or careers of a few individuals, often retired officials - the most notable perhaps ex-President Jimmy Carter's eponymous Carter Center-also proliferated. In a crowded field, many proved short-lived. Major well-established Western foreign policy institutes, often bolstered by substantial endowments, responded creatively. They reached out to a broader membership and constituencies that reflected changing national and international power structures and elites, upgraded their capability to disseminate their intellectual outputs, published and otherwise, developed media strategies, and even called in management consultants. Links to policymakers were also upgraded, with the CFR and Asia Society opening Washington offices in the early 1970s.

More elaborate transnational groupings began to emerge, most notably the Trilateral Commission, an enterprise that initially brought together European, North American, and Japanese specialists, but later expanded its scope to include Chinese participants and other East and Southeast Asians. The banker David Rockefeller, since the late 1960s a reforming CFR chairman, was a leading spirit in this venture. ${ }^{41}$ It was inspired in part by the Asia Society's Williamsburg Conferences, an enterprise initiated in 1971 by his brother, John D. Rockefeller

39 Legge, Australian Outlook; James Cotton, The Australian School of International Relations (New York: Palgrave Macmillan, 2013), passim.

${ }^{40}$ On the sense that international configurations were changing, largely to US disadvantage, see Daniel J. Sargent, A Superpower Transformed: The Remaking of American Foreign Relations in the 1970s (New York: Oxford University Press, 2015), esp. chap. 6.

41 Sklar, ed., Trilateralism; see also Dino Knudsen's forthcoming book on the Trilateral Commission. 
III. The 1970s saw the beginning of serious efforts to integrate Asian elites into the post-1945 international power structure, initiatives in which think tanks-and associated academic institutions - were highly significant, and to which the Asia Society's Williamsburg conferences were likewise crucial. These exclusive private meetings, where a small group of top political, business, media, and academic figures from around non-Communist East and Southeast Asia spent three days every year talking in strict confidence to American, Canadian, Australian, and British counterparts about recent developments in Asia and prospects for the future, soon became an event sui generis. Eventually, in 1980, mainland Chinese representatives, followed by top figures from other Asian communist countries, would join these deliberations. From their inception, these meetings' three co-conveners included not just the Asia Society's Robert W. Barnett, a longtime China expert and retired US diplomat, but also Saburo Okita of Japan (a think tank executive and future foreign minister) and the leading if sometimes politically controversial Indonesian intellectual Soedjatmoko, a former Indonesian ambassador to the United States.

Across Asia, foreign policy institutes proliferated from the 1950s and even more the 1970s onward. Japan was initially the leader in the field, with many such institutions governmentfunded or at least government-backed, including the Japan Institute of International Affairs (JIIA), established in 1959 by the Foreign Ministry. South Korea soon followed suit with various government-sponsored organizations, as did Singapore, where the independent Singapore Institute of International Affairs came into being in 1961 and the government-backed Institute of Southeast Asian Studies was established in 1968. The Malaysian government founded the Institute of Strategic and International Studies (ISIS) in 1983. Elsewhere, their nature was mixed, with privately funded think tanks such as Indonesia's Centre for Strategic and International Studies operating at a certain arm's length from government. East and Southeast Asian foreign policy institutes proved adept at regional networking, notably through the ASEAN Institute for Strategic and International Studies, established in 1981, the Council for Security Cooperation in Asia-Pacific, founded in 1993, and the Network of East Asian Think Tanks, created in 2002. ${ }^{42}$ In 2015, the JIIA's website listed no less than 119 affiliated organizations around the world. ${ }^{43}$ By 2014, China housed 429 of Asia's 1087 think tanks, surpassed only by the 1830 in the United States. From the 1970s onward, government bureaucracies at all levels in China established government-funded foreign policy institutes-usually freestanding but sometimes housed within universities - whose most significant function was to provide informed advice and guidance on their country's developing relationship with the outside non-communist world. Thousands of scholars worked in these centres. While many reflexively toed the prevailing line and steadfastly defended government policies, these organizations sometimes provided bases for intellectuals who questioned Marxist orthodoxy and the existing status quo, developments that on occasion provoked tough party crackdowns on dissent. China's avowed objective of developing internationally respected think tanks to boost its soft power and global standing may indeed be undercut by its government's ingrained habit of harassing or arresting such institutions' personnel when they deviate from prevailing official dictates. ${ }^{44}$

\footnotetext{
${ }^{42}$ McGann with Sabatini, Global Think Tanks, 129.

43 http://www2.jiia.or.jp/en/network.php, consulted March 16, 2015.

44 Adrian Wan, "Chinese Academy of Social Sciences is 'infiltrated by foreign forces': anti-graft official," South China Morning Post, June 15, 2014; Huang, "Chill Wind Blows through Chinese Academy of Social Sciences,” South China Morning Post, August 2, 2014; Huang, “Think Tanks
} 
Western international affairs institutes often responded to the Cold War's end with entrepreneurial enthusiasm and an upsurge in global activity. Some established international outposts, notably the Asia Society in Hong Kong, Manila, Melbourne, Mumbai, Seoul, and Shanghai, and the Carnegie Endowment for International Peace in Moscow, Beirut, Beijing, and Brussels. The CEIP was also exemplary in terms of linking itself into international networks, both institutional and personal, establishing affiliated relationships with a wide range of other organizations and ensuring global and US visibility and impact for its publications and findings. In 2014 it was credited with having the world's third best think tank network, with Chatham House having the world's fifth best. The CFR, currently $27^{\text {th }}$ in terms of such networks, opened its first international office in Hong Kong in 1995, the same year it cut its ties to its forty-odd associated regional committees around the United States; it also upgraded its website, began publishing foreign-language versions of its journal, and improved its outreach and publicity. Large institutes such as the Washington-based Woodrow Wilson Center, founded in the late 1960s, increasingly oriented themselves to understanding and addressing the challenges of an international system in transition, while mounting a major long-term transnational initiative to enhance understanding of the Cold War by pushing to open archival materials from the communist camp. The Wilson Center hosts an impressive range of foreign as well as American scholars; mounts major conferences; has ties to numerous institutions around the world; and publishes highly respected journals and scholarly volumes, both edited and single-authored.

The end of Soviet domination over Eastern Europe likewise prompted an efflorescence of new think tanks across the "transitioning" region, some though not all oriented toward foreign affairs. It also boosted the standing of existing institutes of international affairs, which continued in existence, even as new and more specifically focused organizations were created. Given the salience of the European Union, pan-European networks became particularly significant, and in 2007 a European Council on Foreign Relations was founded, with EU funding and backing from a blue-ribbon assortment of top political figures. Universities likewise responded. At the London School of Economics, from 2008 the IDEAS Centre for the study of International Affairs, Diplomacy, and Strategy, offered a heady mix of first-class scholarship, exciting international visitors and lectures, joint programs to train promising young foreign policy specialists from around the world, high-profile and off-the-record events, and astute publicity, rewarded within six years with the accolade of the world's second-ranked academic think tank. Except in very specific niche areas, however, as with institutions deliberately designed to bolster a specific bilateral relationship, Western institutes that simply remained smallscale, serving a limited catchment group, often found survival problematic and sometimes disappeared or amalgamated with other groups, a fate that befell the venerable CIIA, transformed into the Canadian International Council in 2007. Clingendael, the highly respected Netherlands Institute of International Relations, was a 1983 government-sponsored amalgamation of seven earlier institutes.

For the long-term, the future appeared to lie with those organizations that oriented themselves towards the regional and the global "agora." Perhaps the most remarkable feature of the early twenty-first century was the dissolution of the distinction between domestic and international issues, at least so far as international think tanks and non-governmental organizations were

Face Hurdle in Answering Xi Jinping’s Call," South China Morning Post, November 3, 2014; Stone and Denham, eds, Think Tank Traditions, 141-162; David Shambaugh, "China's National Security Research Bureaucracy,” China Quarterly 110 (1987), 276-304. 
concerned. In Latin America, Africa, Europe, Asia, and the BRICs, regional groupings had become de rigueur, with a BRICs Policy Center operating in Brazil. The African Liberal Network, prudently working from Britain, was created in 2003; a Network of Arab Liberals, based in Egypt, came into existence in 2006; and the Council of Asian Liberals and Democrats, headquartered in the Philippines, was founded in 2008. And regional groupings tended to be linked with and look to still wider global networks. Pursuing international peace can be a protean enterprise. Economic growth, political development, urban planning, women's rights, education, business issues, financial institutions, currency convertibility, corruption, health, energy policy, military and strategic issues, legal reform, religious and cultural divides, clean water, climate change, agricultural policy: all fell within the largely self-assigned but nonetheless influential remit of such organizations as the Carnegie Endowment for International Peace and the World Bank Institute. Rolling Back Malaria has become an international cause with its own network. Previously local and national issues are suddenly and perhaps irretrievably regional and often global in nature.

One scholar has recently questioned the entire credibility of present-day American think tanks, suggesting that they lack fundamental independence and tailor their product to their sponsors' demands. ${ }^{45}$ The neo-conservative Project for the New American Century, an advocacy group founded in 1997 and disbanded in 2006, that pushed for assertive US international hegemony and urged the 2003 invasion of Iraq, is often cited as an example of influential but politically biased shoddy scholarship coloured by wishful thinking. ${ }^{46}$ Where those organizations Diane Stone has termed "the foreign policy club" are concerned, such gloomy expectations seem unduly pessimistic, the outcome of concentrating too exclusively on the American experience. Since the 1970s, and even more so since the 1990s, most of the leading Western international affairs institutes have rethought and restructured their operations, to enable them to function at a global and regional as well as national level, with multiple audiences, clients, associates, and affiliates. A constant stream of high-profile events-lectures, seminars, conferences, briefingsis only one attraction. Many of them offer temporary or permanent appointments to and publish books, reports, and articles by top scholars and experts from around the world, public intellectuals whose outputs may sometimes be controversial, but are generally recognized as academically credible-and sometimes even appealing to a general audience. The same operating pattern characterizes recent arrivals on the scene. Many openly proclaim their commitment to having an impact internationally by participating in "Track Two" diplomacy. Given these organizations' prominence in recent think tank rankings, there is clearly a market for their services that brings them respect and recognition. Non-Western institutes specializing in international affairs also feature disproportionately in world as well as regional think rankings, suggesting that overall, foreign policy organizations are seen as less politicized and more credible than other think tanks.

In an ever more complicated international setting, networked foreign affairs institutes-largely but not entirely Western-led, though sometimes enjoying close ties to non-Western counterpart organizations - appear, singly and in concert, to be seeking to interpret trends, issues, and events to global, regional, and national publics, providing multiple forums for dialogue and debate. Current power configurations among national governments, transgovernmental organizations,

\footnotetext{
${ }^{45}$ Medvetz, Think Tanks in America.

${ }^{46}$ Kubilay Yado Arin, Think Tanks: The Brain Trusts of US Foreign Policy (New York: Springer, 2013).
} 
markets, and civil society institutions offer them space in which to operate effectively. One may argue-as unsympathetic governments and other groups undoubtedly will-that these developments effectively represent a new form of Western intellectual hegemony and unjustified interference in other nations' internal affairs. Yet insulating themselves from these networks may prove beyond the powers of all but the most authoritarian regimes. The prestige and reach of the organizations involved make them almost impossible to ignore, with much of their output feeding into the global intellectual agenda. Furthermore, they normally seek to encourage dialogue with those of different persuasions, offering platforms for opponents to set forth their own positions, both publicly and in private, in the hope of coopting and integrating them into the existing order. However aggravating dissenters may find some of their positions, for most who feel themselves on the periphery of these institutes' operations, they are simply too useful to be ignored or boycotted. Like other Western think tanks, the international affairs institutes currently provide models whose workings others planning to set up think tanks of their own often scrutinize in great detail, even if subsequently adapting them to specific local conditions. International affairs think tanks - the preferred locution on Chatham House's website-emerged around a century ago, when the existing international system was already buckling and under the pressures of major war eventually collapsed. In the early twenty-first century, a globalized but fractured world with an international system in flux conceivably offers the potential for what is now a loose network of interlocking organizations transcending national boundaries to enjoy a new golden age of unprecedented influence. 